\title{
Sustainability Balanced Scorecard: Four performance perspectives or more?
}

\author{
Sanda Rašić Jelavić \\ University of Zagreb, Faculty of Economics \& Business, Zagreb, Croatia \\ Mirna Pajdaković Vulić \\ Janaf d.d. Zagreb, Croatia
}

\begin{abstract}
This paper analyzes the Sustainability Balanced Scorecard (SBSC) as a renewed framework for measuring and managing sustainability performance of a company. The paper presents the main characteristics of original Balanced Scorecard (BSC), explains its purpose and main performance perspectives. Based on literature review, paper address the various approaches to design and prioritize performance perspectives within the SBSC. Firstly, casual links within and between performance perspectives are described: hierarchical links (as is in original BSC approach), semi-hierarchical links and network links. Secondly, the paper explains how the sustainability issues are incorporated within SBSC framework. Several solutions are explained as suggested in the literature: (1) adding additional single or multiple performance perspectives to deal with strategically important sustainability issues, (2) incorporating sustainability aspects within original four performance perspectives, (3) adding additional sustainability perspectives and incorporating sustainability aspects in four original performance perspectives simultaneously, (4) organize separate SBSC for managing only sustainability issues. Specific features of these approaches are explained as well as appropriateness of their application in practice. Advantages and disadvantages of SBSC are highlighted and recommendations for future research.
\end{abstract}

Keywords

Sustainability Balanced Scorecard, corporate social responsibility, environmental protection

\section{Introduction}

Various systems for measuring and managing business performance are developed in order to facilitate monitoring of the goal achievement and the position of the company. These systems refer to the collection, processing and analyzing the information about company performance which serve as the basis for decision-making processes. Measuring performance helps to assesses whether and to what extent the goals have been achieved, whether there is a discrepancy between planned and achieved performance, and what should be done to eliminate it. Hence, systems for measuring and managing performance enable managers to monitor, manage, and improve business performance, maximize progress efforts and motivate workers in task accomplishment
(Kellen \& Wolf, 2003). These systems include formal routines and procedures, based on gathered information, which help managers to better navigate in managing performance dimensions (Simmons 2000). The use of systems for measuring and managing performance gains special importance in large companies where supervision, control and coordination of the organizational activities and goal accomplishment becomes more difficult. Nevertheless, some researchers (Dudic, Dudic, Gregus, Novckova \& Djakovic, 2020) found that the use of BSC is important in SME business as well because it facilitates innovative activities and effect the development of those companies positively.

One of the performance measuring and managing systems is the Balanced Scorecard (BSC) System. It is a tool for balancing various 
measures of a company's success through harmonizing financial and non-financial performance, short-time and long-time performance, qualitative and quantitative performance, external stakeholder (customer) needs and internal stakeholder (owner) needs that are organized hierarchically within the main performance perspectives (Kaplan \& Norton, 1992; 1996; 2001). Kaplan and Norton (1996) state that additional perspective could be incorporated in BSC depending on industry type and/or business strategy.

The need for creating the Sustainability Balanced Scorecard (SBSC) appeared as a consequence of orientation toward corporate social responsibility (CSR). CSR is a managerial approach through which a company contributes to sustainable development, considering not only interests of a company but concerns of other stakeholders as well (World Bank). Within CSR organizations conduct business in ethically sound and responsible way that goes beyond the legislation or other external requirements, aiming to achieve environmental and social quality while preserving profitability (Osagie, Vesselink, Blok, Lans \& Mulder, 2014). The concept of sustainable development is characterized by "3Ps" - (People, Planet, and Profit/Prosperity), which highlights the importance of balancing among "social, natural, and financial resources" (Osagie et al., 2014).

Various approaches have been developed to renew the original $\mathrm{BSC}$ that will adjust sustainability requirements (Figge, Hahn, Schaltegger \& Wagner 2002). In other words, original $\mathrm{BSC}$ have been modified to consider economic, environmental, social or other nonmarket perspectives. The literature offers various approaches to structuring the SBSC. Some scholars offer modification within four dimensions of original BSC, while other assume it is better to add additional dimensions regarding sustainability issues. Furthermore, there are differences in approach how to link elements of various SBSC dimensions and how to link their strategic objectives.

\section{Business performance measurement and management systems}

Systems for measuring and managing business performance can be perceived as a cycle of performance planning, performance execution and performance evaluation aiming to achieve strategic goals (Vrdoljak Raguž, 2010). This requires the measurement of results (such as an amount of product or some other type of realization) and the measurement of process parameters that affect the realization of output (Bakotić, 2012). It is necessary to determine what will be measured, what will be the key performance indicators, what will be the sources of performance data, how the data will be collected and the specification of measurements (Sehić \& Dizdarević, 2011). Performance indicators assess not only the company as a whole, but could also assess departments, processes, programs, products or services, projects, and organized teams and groups within the company (Vrdoljak Raguž, 2010). In this sense, one can distinguish between performance measures on corporate, divisional, functional, individual level etc.

Systems for measuring and managing business performance are usually based on wide number of performance indicators (evaluated from different points of view), which include financial and nonfinancial measures. Most often used indicators are financial indicators, such as return on assets (ROA), return on equity (ROE), return on investment (ROI), return on capital employed (ROCE), economic value added (EVA), market value (MV), market value added (MVA) etc. These traditional performance measures focus on the overall financial results that the company has achieved over a period of time. Although important, they provide little insight into why and how certain results have been achieved. Furthermore, there is an understanding that traditional financial measures are only onedimensional and that long-term success of a company needs to be based on more holistic performance measures. The performance indicators should serve not only to describe past events, but should help the company to understand the present situation and lay the foundations for future directions (Montemari, Chiucchi \& Nielsen 2019). Therefore, multidimensional performance measures are developed that take into account various performance perspectives. Such approaches to business performance measurement and management are Balanced Scorecard System (BSC), Total Quality Management (TQM), Performance Measurement Matrix (PMM), Performance Prism (PP), EFQM's business excellence model, Macro Process Model, SMART Performance Pyramid, Results and Determinants 
Framework (RDF), Holistic Performance Management Framework (HPFM), the Dynamic Multidimensional Performance Framework (Sooroshian, Aziz, Ahmad, Jubidin \& Mustapha 2016), Value Based Management (VBM), Activity Based Costing (ABC), etc.

Systems for measuring and managing business performance have certain common functions: control function (based on comparison of planned and achieved results); development and guidance function (they serve as the basis for strategy formulation and implementation); motivational function (they encourage the achievement of goals). Regardless of which measurement systems the company chooses, it is necessary for performance indicators to be (Sehić \& Dizdarević, 2011): understandable, interconnected, suitable for defined goals, easily measurable and cover all aspects and critical success factors.

\section{Balanced Scorecard (BSC)}

The BSC was introduced by Kaplan and Norton (1992) and refers to comprehensive methods of measuring and managing performance, oriented to monitor indicators that directly affect organizational strategy. What the BSC system provides to organizations is a multi-perspective framework through which organizational vision and strategy are transformed into a coherent system of strategic objectives, performance indicators, targets and initiatives.

\subsection{Characteristics of the Balanced Scorecard (BSC)}

The model of BSC provides a carefully selected set of measures that have strategic importance. The usefulness of BSC comes from the situation that one of the fundamental strategic problems is related to the strategy implementation as well as operationalization through the lowest organizational levels. A properly designed system of the BSC shapes the strategic side of business, determine basic business perspectives and strategic initiatives that should be taken to achieve defined goals within these performance perspectives. Therefore, it serves as a significant instrument to support strategy implementation.

To make the BSC operational, a methodology of strategic maps was introduced. Strategic maps show the casual linkage among strategic goals among and within performance perspectives, from the lowest to the highest level (Kaplan \& Norton 2001; 2004). Maps provide a framework by which in a reasonable and logical way the strategy descends from the highest to the lowest levels of the organization, creating BSC's architecture. By creating causal hierarchical relationships between goals, initiatives and results, methodology of strategic maps can clearly identify how the strategy is transmitted throughout the organization. In order to be relevant, the development of strategic maps is based on annual reports, mission and vision statements, values, project plans and initiatives, consulting studies and similar documents that provide a fundament for understanding the current position of the company and its orientation in forthcoming period.

\subsection{Performance perspectives of the Balanced Scorecard (BSC)}

Traditional BSC system allows managers to look at a company's performance answering to fundamental questions in four important perspectives (Kaplan \& Norton, 1996).

The first is financial perspective, which provides insight into the organizational achievements and goals from the financial aspect. It shows how and to what extent the strategy helps in improving the financial results of the company. The financial goals have been set in the short run and long run, whereby companies strive to achieve the highest possible return on investment to secure the business prospective. Performance indicators for financial goals are often considered as the most important and result from all other factors over a period of time. At its core, this perspective encompasses traditional methods of measuring finance. Within the system of benchmarks and indicators, this perspective show what will motivate shareholders and other investors to invest in the company and to keep the shares.

In practice, most companies use the following financial measures (Belak, 2002): (1) business growth (revenue growth, asset growth or income from new products and services etc.), (2) business profitability (profit margin, return on investment, return on assets, profit per employee etc.), (3) value creation for owners - (economic value added, market value added, dividends or stock prices etc.). Atkinson, Kaplan, Matsmura and Young (2007) emphasize that value creation for shareholders is achieved through: (1) revenue growth, which is realized either by new products/services or increasing the profitability of the existing products/services, by deepening relationships with customers, increasing the 
product value, (2) productivity improvement, achieved through cost reduction and more efficient management of existing assets.

Within financial perspective, one should be careful when interpreting indicators. Financial indicators give a picture of past activities of the company, and although they provide a basis for forecasting, these indicators do not provide much information about the processes of value creation in the future. Yet, the system of balanced objectives cannot be applied without financial perspective (consideration of the financial aspects). Furthermore, the results in other performance dimensions ultimately effect the financial performance.

The customer perspective includes defining the goals and indicators in customer segments and in certain markets. Satisfied loyal customers are important precondition for future business growth (Lončarević, 2006) and are achieved through the customer value creation (includes quality, design, technological advancement, size, availability, time, service, expenditures etc.). Creating customer value is an indispensable part of any strategy. Market segmentation allows the company to select target segments and to identify customer-related goals in those segments. The company needs to supply customers with products/services that are better than those of competitors and are tailored to satisfy specific customer needs in selected markets. Customer perspective incorporate customer and market oriented processes including marketing activities aimed at maintaining the brand, retaining existing customers and gaining new customers (Gulin, Janković, Dražić Lutilsky, Perčević, Perišić \& Vašiček, 2011).

Some of common measures of customer perspective are: customer loyalty, customer acquisition, customer profitability and sales growth, (Atkinson et al., 2007). Additional measures within customer perspective are: customer satisfaction, customer retention, the value delivered to the customers, customer complaints, the share of key customer accounts, product return rate, the number of partnerships with customers, etc. These measures are the basis for the development of marketing, operation, logistics, production and service processes, but they also derive from them and directly affect the financial indicators. Unlike the indicators within financial perspective, which are obtained from the basic financial statements, indicators of the market dimension require research through surveys and questionnaires on a specific sample of customers.

The process perspective (perspective of internal processes) reflects upon the internal elements of the company. This dimension includes identifying the core organizational processes that are crucial for increasing business performance and such processes must be perceived as very important in BSC system based on continuous improvement. The fundamental task of operative processes is the production and delivery of valuable products/services to the customers, but these processes serve to improve other organizational processes, to reduce costs and leverage better productivity in financial terms (Sofiyabadi \& Nasab, 2012). The goals of process dimension are set after the goals in financial and market dimension, because the way of implementing the processes are set in order to achieve higher level goals and contribute to the value creation within the company. The following key processes are often determined within this perspective (Atkinson et al., 2007): (1) operational processes - include activities from the production to delivery (procurement, production and distribution of the finished product or service to customers); (2) customer management processes - includes activities that furtherly develop customer relations (selection and acquisition of customers, customer retention, increasing business with customers); (3) innovation processes - refers to constant innovation while focusing on customer needs (depends on the ability of employees to be innovative and turn new innovations into new products and services), (4) social processes and regulatory processes (activities to adhere to a set of national and local regulations, activities to promote the common good of the community etc.).

Measures that can be used for this performance perspective are (Kaplan \& Norton, 1992; Belak, 2002): time to market (in relation to the plan or in relation to competitors), production cycle time, delivery cycle time, manufacturing capability vs. competitors, equipment effectiveness, number of defective products, debugging runtime, asset utilization, inventory turnover, unit costs, engineering efficiency etc.

The learning and growth perspective emphasizes the importance of intangible drivers of company performance, covering a wide range of areas related to human, information and organizational capital. This dimension primarily 
emphasizes the importance of investing in human capital and employee capabilities that leverage business development. The core of this dimension is the orientation towards the future, based on constant learning, growth and employee development. Ideas and incentives to increase performance and improve processes should come from employees at all organizational levels who participate in internal processes and are in direct contact with customers. The base is motivation and education of employees on knowledge needed to accomplish company's vision and long-term strategies. Learning and development perspective emphasizes the importance of investing in human potential, whereby the measurement focuses on development of employee potential, motivation and goal orientation (Gulin et al., 2011). This dimension measures the level of motivation and goal achievement, the strategic potentials of human resources and the information system (Lončarević, 2006). This requires in particular the motivation of employees by top management who should set values of learning and development as fundamental values within organizational culture.

Measurement in the area of learning and growth is not simple because it largely relates to difficult-to-measure and intangible elements. Kaplan \& Norton (2001) differentiate between three main measurement areas: employee retention, employee satisfaction and employee productivity. Additional areas could be included in this perspective such as "information systems" and "organizational alignment (culture, leadership and teamwork)" (Gekonge, 2005). Commonly used measures within this perspective are: retention rate, worker satisfaction score, worker motivational index, worker qualification index, training rate, number of worker suggestions, improvement of personal goal achievement, income per employee, value added per employee, investment in innovations, technological support of the processes, informatization level, measures of organizational culture (Medaković, 2010: Belak, 2002) etc.

\section{Sustainability Balanced Scorecard (SBSC)}

To create the SBSC, environmental and social objectives and performance measures are explicitly included within the original BSC framework, in addition to financial objectives.

Financial goals that are additionally incorporated within financial perspective of the SBSC might be: increasing return of sustainability investment; reducing the costs based on energy savings, lower consumption, social issues and environmental tax; increasing additional revenue by environmentally friendly ("eco") products, increasing income from recycling or cycling schemes, increasing income from sustainability improvements (Hristov, Chirico \& Appolini, 2019 ) etc. World Business Council for Sustainable Development (2005) emphasizes the importance of adding objectives such as ecoefficiency and socio-efficiency (The value of Product/Services / Environmental or Social Value) to accompany financial objectives.

Environmental objectives cover various objectives ranging from reducing air, water and soil emissions, reducing waste, reducing resource consumption, reducing hazardous material consumption and waste to increasing the proportion of renewable energy use, improving energy efficiency, improving resource efficiency, improve recycling and reuse of products, reducing noise and vibrations, etc.

According to the huge variety of social issues and the lack of unanimous approach, it is not easy to create a general framework of social aspects (Hristov et al., 2019). Social objectives incorporated within SBSC could be ensuring ethically conduct business, ensuring fair-trade supply, improving health and safety, increasing philanthropy and donations to local or other selected communities, increasing local economic development etc.

Financial (economic) performance are mostly evaluated by quantitative indicators, while environmental and sustainability performance are assessed using quantitative and qualitative indicators. To measure environmental performance, the key performance indicators (KPI) are developed within various frameworks (such as standard ISO 14001) as well as KPI that are developed under frameworks for measuring sustainability performance (such as Global Reporting Initiative).

\subsection{Cause-and-effect linkages of the SBSC}

Based on the literature review, Hansen and Schaltegger (2016, 2018) explain various approaches in structuring the SBSC in comparison to traditional BSC system. Regarding casual linkage among performance perspectives and their strategic objectives, several approaches are offered: (1) the first approach suggests sustaining original hierarchy of BSS "performance perspectives and strategic objectives", with 
financial performance as an end point (Figge et al., 2002), (2) the second approach proposes a semi-hierarchical framework among various performance perspectives and strategic aims (Sundin, Granlund, \& Brown, 2010), (3) while the third approach argues the need to create network structure among them (van Marrewijk, 2004).

The first approach retains the strict hierarchy of original BSC in which other strategic objectives have to lead to economic (financial) goals. This approach is based on profit-driven value system that focuses toward profit maximization. Therefore, social and environmental objectives subordinate economic (financial) objectives. Environmental and/or social goals are incorporated in casual links to facilitate achieving financial performance perspective, with ultimate profit-driven aims. In that case, the sustainability goals and initiatives that will be accepted are those that eventually influence financial results positively. Yet, the problem might appear, especially if certain sustainable initiatives that could bring radical improvement are rejected because of long-term payback period or uncertainty. Some scholars (Schaltegger \& Wagner, 2011; Hockerts \& Wüstenhagen, 2010) emphasize it is important to assure that profit prioritization does not become an obstacle but helps in developing sustainability initiatives that requires healthy financial base.

The second approach argues that there are no strict causal relationships from other strategic objectives toward financial performance (Hsu, $\mathrm{Hu}$, Chiou \& Chen 2011). Relationships among these objectives are not linear and in one-way direction all the time, as mutual interdependencies among them may exist (Brignall, 2002). Such approach emphasizes the importance of all three objective areas (economic, environmental, social) aiming to balance among them and achieve results that are at least minimally acceptable along all perspectives. Environmental and social objectives are not necessarily used as a source for ultimate financial goals (Chaker, Idrissi \& Manoar, 2017). An example is setting triple bottom line strategic objectives instead of only financial bottom line (van Marrewijk 2004).

According to the third approach, perspectives are interlinked within network architecture (Bieker \& Waxenberger, 2002) or set independently of others (Voelpel, Leibold \& Eckhoff, 2006). No particular perspective is targeted as ultimate goal with highest priority. Economic, environmental and social objectives are equally significant (Bieker \& Waxenberger, 2002; Hubbard, 2009; Voelpel et al., 2006; Nikolaou \& Tsalis, 2013) where no single goal predominates.

In the second and third approach, where there is no strict hierarchy toward financial strategic goals, managers have to deal with the balancing among various objectives that might be conflicting and require compromise, especially when win-win solution could not be achieved (Jensen, 2001). It is emphasized that trade-offs between conflicting objectives, which is demanding task for strategy experts, should be resolved during strategy formulation (Hansen \& Schaltegger, 2016). Setting a priority system regarding these objectives could be helpful in this process.

Appropriate approach regarding casual linkage between performance perspectives and their objectives will depend on the development and maturity of sustainability strategy and significance of certain environmental, social and other nonmarket elements in future orientation. The second and the third approaches could be appropriate where companies follow more advanced sustainable strategies.

\subsection{Performance perspectives of the SBSC}

Regarding the number of performance perspectives within SBSC framework, dilemma is whether to incorporate sustainability issues within the four existing perspectives or create additional fifth or sixth perspective dedicated to sustainability issues (Epstain \& Wiesner, 2001; Hubbard, 2009).

The first approach offers ability to supplement additional one or more perspectives oriented toward sustainability objectives within SBSS framework (Sidiropoulos, Mouzakitis, Adamides, \& Goutsos, 2004; Hubbard, 2009) so there will be overall five or six perspectives. Such approach puts a great value on sustainability aspects and allows the company to organize sustainability management separately. An additional performance perspective might be organized around environmental and social aspects (aimed to achieve sustainability goals), or additional two performance perspectives can be formed to manage environmental and social goals separately. Schaltegger and Wagner (2006) emphasize that such approaches could be taken if additional sustainability perspective has long-term strategic aims that do not adequately commit to economic objectives, but states that even in that 
case sustainability perspectives should not be completely detached from conventional perspectives, because the natural connection among them exist.

The second possibility is to incorporate sustainability aspects within original four perspectives of the BSC framework (Gminder \& Bieker, 2002; Dias-Sardinha \& Rejinders, 2005; Sundin et al., 2010; Watti \& Koo, 2011; Nikolaou \& Tsalis, 2013). Sustainability issues could be only partly integrated in one or more perspectives, or could be deeply integrated in all four perspectives.

In the case of partial integration of sustainability aspects, it is usually done within the perspective of internal processes. This may happen if environmental issues are managed mainly at operational process level. Within process perspective, environmental objectives might be: improving transport efficiency, improving energy efficiency, increasing water recycling, improving environmentally friendly packaging, increasing resource productivity, reducing waste and wastewater, reducing the use of toxic materials, increasing quality control through the value chain, recycling production and office materials, eliminating environmental accidents and spill, etc. Example of social objective in process perspective could be assuring health and safety.

If sustainability aspects are integrated more deeply in all four perspectives, it is based on greater dedication of a company toward achieving corporate social responsibility. In that case sustainability problems are managed within all four performance perspectives, not only in process perspective. Table 1 shows sustainability performance measures within main four perspectives of the SBSC.

Table 1 Sustainability measures integrated in the SBSC with four performance perspectives

\begin{tabular}{|c|c|}
\hline FINANCIAL PERSPECTIVE & STAKEHOLDER PERSPECTIVE \\
\hline $\begin{array}{l}\text { Environmental aspect } \\
\text { - } \quad \text { eco-efficiency } \\
\text { - } \quad \text { return on environmental investment } \\
\text { - } \quad \text { recyenues from "eco" products/services revenues } \\
\text { - } \quad \text { operating costs } \\
\text { - } \quad \text { cost savings from environmental improvements } \\
\text { - } \text { disposal costs } \\
\text { - } \quad \text { costs of reactive environmental initiatives/costs of proactive } \\
\text { - } \quad \text { environmental initiatives } \\
\text { - } \quad \text { environmental fines and penalties } \\
\text { Social aspect } \\
\text { - } \quad \text { socio-efficiency } \\
\text { - } \quad \text { inilanthropy/donation expenditures } \\
\text { invent in development of local community }\end{array}$ & $\begin{array}{l}\text { Environmental aspect } \\
\text { - } \quad \text { the value of "eco" products/services, } \\
\text { - } \quad \text { customer satisfaction with "eco" products/services } \\
\text { - } \quad \text { brand reputation of "eco" product/services } \\
\text { - } \quad \text { image of environmentally responsible company } \\
\text { - } \quad \text { strength of regulatory relationship/complying with future } \\
\text { - } \quad \text { relationship with sustainable suppliers } \\
\text { - } \quad \text { relationship with bankers } \\
\text { - } \quad \text { press coverage } \\
\text { Social aspect } \\
\text { - } \quad \text { community satisfaction } \\
\text { - } \quad \text { community complaints } \\
\text { - } \quad \text { transferring the knowledge to the local community }\end{array}$ \\
\hline PERSPECTIVE OF INTERNAL PROCESSES & PERSPECTIVE OF LEARNING AND GROWTH \\
\hline $\begin{array}{ll}\text { Environmental aspect } \\
\text { - } & \text { operative efficiency } \\
\text { - } & \text { energy efficiency } \\
\text { - } & \text { environmentally friendly packaging } \\
\text { - } & \text { resource productivity } \\
\text { - } & \text { waste } \\
\text { - } & \text { wastewater } \\
\text { - } & \text { greenhouse gas emission } \\
\text { - } & \text { use of recycled materials } \\
\text { - } & \text { recycling rate for production and office materials } \\
\text { - } & \text { product reuse rate } \\
\text { - } & \text { number of environmental accidents and spills }\end{array}$ & $\begin{array}{l}\text { Environmental aspect } \\
\text { - } \quad \text { environmental awareness of employees } \\
\text { - } \quad \text { environmental skills of employees } \\
\text { - } \quad \text { knowledge on environmental protection } \\
\text { - } \quad \text { "eco" innovations } \\
\text { - } \text { development of environmental infrastructure } \\
\text { - development of environmentally friendly materials } \\
\text { Social aspect } \\
\text { - } \quad \text { hiring from local community } \\
\text { - } \quad \text { employee wellbeing } \\
\text { respecting diversity }\end{array}$ \\
\hline $\begin{array}{l}\text { Social aspect } \\
\text { - } \quad \text { workplace health and safety }\end{array}$ & \\
\hline
\end{tabular}


The base for environmental improvement and innovation lies in development of knowledge which is part of learning and growth perspective. In that perspective, environmental objectives could be: increasing environmental awareness, increasing environmental skills of employees, increasing training on environmental-protection knowledge, improving eco-innovations, developing environmental knowledge base, improving environmental infrastructure and resources (equipment, materials), increasing motivation toward achievement of environmental goals etc. An example of social objective is to increase hiring from local community, increasing employee wellbeing, decreasing violation reported by employees, respecting diversity etc.

Regarding customer/market perspective in the SBSC, some scholars (Journeault, 2016; DiasSardinha \& Reijnders, 2005) suggest renaming it into stakeholder perspective. Environmentally friendly ("eco") products/services, based on green innovations, are integrated into this perspective. Environmental objectives in this perspective could be: improving the value of "eco" products/services, improving customer satisfaction with "eco" products/services; customer wellbeing, increasing the sales of "eco" products/services; improving the image of environmentally responsible organization; reducing the risk associated with future environmental regulation; good relationship with bankers and other "green" investors, improve favorable press coverage, etc. An example of social objective could be increasing community satisfaction, increasing philanthropy, donations and volunteering activities, transferring the ecoknowledge into local community, decreasing community complaints etc.

Within financial perspective, various environmental objectives could be incorporated, such as increasing eco-efficiency, cost savings from environmental improvements, increase in revenues from "eco" products/services (Bieker, Dyllick, Gminder, \& Hockerts, 2001) increasing return on environmental capital investment, improving recycling revenues, reducing disposal costs, reducing fines and penalties, decreasing the costs of proactive environmental initiatives in relation to the costs of reactive environmental initiatives etc. (Epsteein \& Wisner, 2001). Social goals within financial perspective could be increasing socio-efficiency, increasing expenditures of knowledge transfer, philanthropy, donations, development of local or other selected communities etc. Some scholars that argue semihierarchy or network architecture suggest renaming financial perspective into sustainability perspective (Dias-Sardinha \& Reijnders, 2005; Hsu et al., 2011).

It is suggested that companies might simultaneously follow both approaches i.e. integrate sustainability issues into original four BSC performance perspectives and add additional one or two sustainability perspectives on aspects of strategic importance (Hansen \& Schaltegger, 2016; Figge et al., 2002; Hristov et al., 2019). That approach is usually used in the case of the most developed and proactive sustainability strategy.

Some scholars suggest incorporating additional performance perspectives within the SBSC, such as Ethics (Bieker \& Waxenberger, 2002) and Corporate Governance (Dias Sardinha \& Rejinders, 2005) claiming that governance appeared as a significant factor that explains not only the financial crisis, but also the differences in corporate performance across countries (Mitton, 2002).

Butler, Henderson and Raiborn (2011) suggest that there is a possibility to create separate SBSC, which can be appropriate for companies that did not previously create the BSC system, but want to manage sustainability with the BSC tool or for companies which already have the BSC but do not want to change it, emphasizing that certain problems might appear if environmental initiatives miss the connection to other perspectives.

Comparing the use of SBSC with 4 performance perspectives and SBSC with 5 performance perspectives in making environmental investment decisions, Jiangtao and Pin (2010) did not find significant difference between them, but find that participants needed more time to utilize SBSC with 5 perspectives than SBSC with 4 perspectives. Kaplan and Wisner (2009) concluded that environmental measures were less emphasized in judgments regarding decision-making in SBSC with 5 performance perspectives then in SBSC with 4 perspectives when communication about environmental objectives was on low level, but when communication was at a high level, environmental parameters were more emphasized in 5-perspective $\mathrm{SBSC}$ then in 4-perspective SBSC. Jassem, Che Azmi and Zakaria (2018), (Jassem, Zakaria \& Che Azmi 2020) assume that the link between SBSC architecture (refer to the 
number of performance perspectives) and decision-making process in environmental protection is not always forthright and that they are connected through mediation variables such as knowledge on SBSC and strategic risk knowledge.

\section{Conclusion}

The purpose of performance measurement and management systems is to achieve goals, enable business continuity, monitor the implementation of activities and ensure optimal use of the company's potential. Simmons (2000) considers business performance measurement is the tool that can be used to strike a balance between: different demands placed on an enterprise.

Accordingly, the Balanced Scorecard System (BSC) considers the sufficient importance is given to different aspects of the business. Advantages of the BSC are connectivity and balance among various market and non-market areas, inclusion of financial and non-financial performance indicators, current and forthcoming business aspects. It is assumed that otherwise BSC system would not be efficient enough. BSC measures reflects overall organization "health" as opposed to solely traditional performance accounting measures based on the past period. BSC provides an assistance in strategy planning, implementation and operationalization to the lowest organizational levels. However, Hočevar (2007) points out certain issues regarding insufficient completeness of BSC model (refers to the main perspectives that are not completely comprehensive, although they cover many business areas) and the problem of the wide scope and amount of information, time and commitment required to create BSC model.

Advantages of the Sustainability Balanced Scorecard (SBSC) are ability to support sustainability initiatives, to help in planning and implementation of sustainability strategy and usability for multiple stakeholders (internal and external). SBSC serves as the tool to connect the strategic and operative organizational levels by choosing sustainability initiatives that are important for achieving company's prosperity (Falle, Rauter, Engert, \& Baumgartner, 2016; Searcy, 2012). It is generally agreed that SBSC is useful for assessing future investing options by integrating sustainability aspects in management approach (Huang, Pepper \& Bowrey, 2014). Yet, it is pointed out that the SBSC is not intended to be the completely independent tool for sustainability strategy formulation, or for setting sustainability priorities or for facilitating radical changes toward sustainability (Hansen \& Schaltegger, 2016).

Scholars still struggle to find the most appropriate way to create SBSC architecture that will be the effective framework for measuring and managing sustainability performance. There are various approaches regarding casual links within and between performance perspectives. The approach based on strict hierarchy with the financial perspective on the top, argues that the profit goal is not a barrier but is a precondition for survival as it serves as a source of sustainability investments and sustainability initiatives (Hockerts \& Wüstenhagen, 2010; Schaltegger \& Wagner 2011). Yet, it is emphasized that profit prioritization should not become a way to marginalize sustainability issues and way to limit sustainability progress. Hence, SBSC literature has offered advanced models of casual linkages within and between performance perspectives, such as semi-hierarchical or non-hierarchical (flat network) model. Semi-hierarchical model offers the possibility to focus on multiple objectives simultaneously (economic, environmental and/or social), while network model assumes that all objectives are equally important. It is assumed that semi-hierarchical and non-hierarchical models better illustrate the essence of the relationship between economic, environmental and social systems. The literature emphasizes that the use of these two models (semi-hierarchy and network) requires struggling with numerous tradeoffs between market and non-market objectives, when win-win solution couldn't be found. Nevertheless, semi-hierarchy and non-hierarchy models are considered to be more appropriate for companies with advance sustainability strategies. Yet, to address this issues additional empirical researches are needed to investigate effectiveness of these renewed casual relationships (semihierarchy and network) to offer more evidence and fulfill this SBSC literature gap.

The next research dilemma is how to integrate sustainability issues within SBSC framework. Several approaches are offered in SBSC literature: (1) to add single or multiple additional perspectives dedicated to sustainability issues, i.e. expand SBSC model to five or six performance perspectives, (2) to integrate sustainability aspects into SBSC with four original perspectives, (3) to follow both approaches simultaneously (adding new sustainability perspectives and supplying 
existing four perspectives with sustainability principles), (4) to formulate separate SBSC dedicated exclusively to sustainability issues. Adding additional perspectives dedicated to sustainability issues could be chosen if the company focus on long-term sustainability objectives that do not completely fit with shorttime profit (economic) priorities. But, it is assumed that in that case problems might appear due to the lack of connections and synchronization between market and non-market performance perspectives. The same problem could appear in the last approach (where separate SBSC for managing sustainability issues has been formulated). The use of separate SBSC might be encouraged by the fact that company did not previously have the BSC or had the BSC but did not want to modify it.

The level of incorporating sustainability in business objectives and strategy will depend, among others, on environmental context and external incentives (may vary according to the industry type and sector, environmental legislation, market demand for environmentally friendly products, social demand, demand of responsible investors and bankers, activists etc.) and internal motives (image improvement, brand improvement, marketing improvement, increase in sale of environmentally-friendly products, resource productivity improvement, risk control, better employee motivation, better competitiveness etc.). Hence, selected environmental strategy will consequently determine which of the presented SBSC architectures, regarding the number of performance perspectives and type of linkage among them, would be chosen. It could be concluded that appropriate SBSC architecture will depend on the level at which sustainability is woven into the organizational vision, mission, goals, and strategy, whether the sustainability issues are managed only on process level or on overall organizational level, whether the focus is on environmental control or on environmental prevention, whether the focus is on incremental environmental changes or on radical and fundamental ones etc. If sustainability issues are managed only at operational level, focused more on pollution control and incremental sustainability improvements, then the aspect of sustainability could be included only partially in the SBSC framework which is often done within perspective of internal processes, not within other three performance perspectives. On the other hand, if the company is more focused on pollution prevention, strives for comprehensive sustainability changes and when sustainability principles are incorporated throughout the whole company, the aspect of sustainability needs to be included into all four dimensions of SBSC, or an additional fifth or sixth sustainability dimension should be added, or these approaches could be combined. Furthermore, the separate SBSC for managing only sustainability performance could be formed, but in that case sustainability issues should not be completely detached from other aspects of strategic management and from other performance dimensions.

Jassem et al (2020) found that knowledge on SBSC and strategic risk are significant variables that moderate the relationship between SBSC architecture (SBSC with 4 performance perspectives vs. SBSC with 5 performance perspectives) and environmental decision-making outcomes. Therefore, sufficient knowledge on SBSC and strategic risk knowledge are important base for effective use of the SBSC and for the progress along sustainability avenue. Yet, more evidence is needed to examine variables that influence the effectiveness of chosen SBSC architectures in achieving sustainability success, so future research should be oriented toward deeper examination of that issues to provide additional insight.sm

\section{References}

Atkinson, A. A., Kaplan, S. R., Matsmura, M. E., \& Young, M. S. (2007). Management accounting. New Jersey: Pearson Education Inc.

Bakotić, D. (2012). Organizacijske razine mjerenja performansi. Praktični menadžment, 3(4), 57-61. Retrieved October 1, 2020, from https://hrcak.srce.hr/96966.

Belak, V.(2002). Bilanca postignuća u planiranju i praćenju rezultata poslovanja. RRiF, 11, 1-20. Retrieved August 20, 2020, from https://www.rrif.hr/clanak-3853/.

Bieker, T., Dyllick, T., Gminder, C. U., \& Hockerts, K. (2001). Towards a sustainability balanced scorecard: Linking environmental and social sustainability to business strategy. In Conference proceedings of business strategy and the environment 2001, Leeds, 21-31. Retrieved 15 August 2020, from https://link.springer.com/article/10.1007/s10551-0142340-3.

Bieker, T., \& Waxenberger, B. (2002). Sustainability balanced scorecard and business ethics: Developing a balanced scorecard for integrity management. In Hansen, E.G., \& Schaltegger, S. (2016). The Sustainability Balanced Scorecard: A Systematic Review of Architectures. Journal of Business Ethics, 133, 193-221. https://doi.org/10.1007/s10551-014-2340-3 
Brignall, S. (2002). The unbalanced scorecard: a social and environmental critique. In Hansen, E.G., \& Schaltegger, S. (2016). The Sustainability Balanced Scorecard: A Systematic Review of Architectures. Journal of Business Ethics, 133, 193-221. https://doi.org/10.1007/s10551-014-2340-3

Butler, J. B., Henderson, S. C., \& Raiborn, C. (2011). Sustainability and the balanced scorecard: Integrating green measures into business reporting. Management Accounting Quarterly, 12(2), 1-10. Retrieved 25 August 2020, from

https://www.imanet.org/media/0d2d9a8868844f589794 50f2b02df2b1.ashx

Chaker, F., Idrissi, M. A. J., \& Manouar, A. E. (2017). Acritical evaluation of the Sustainability Balanced Scorecard as a decision aid framework. International Journal of Applied Engineering Research, 12(14), 42214237. Retrieved 20 September 2020, from https://www.ripublication.com/ijaer17/ijaerv12n14_23.pd $f$

Dias-Sardinha, I., \& Reijnders, L. (2005). Evaluating Environmental and Social Performance of Large Portuguese Companies: A Balanced Scorecard Approach. Business Strategy and the Environment, 14, 73-91. https://doi.org/10.1002/bse.421

Dudic, Z., Dudić, B., Gregus, M., Novckova, D., Djakovic, I. (2020)._The Innovativeness and Usage of the Balanced Scorecard Model in SMEs. Sustainability, 12, 1-22. http://dx.doi.org/10.3390/su12083221

Epstein, M. J., \& Wisner, P. S. (2001). Using a Balanced Scorecard to implement sustainability. Environmental Quality Management, 11(2), 1-10. https://doi.org/10.1002/tqem.1300

Falle, S., Rauter, R., Engert, S., \& Baumgartner, R. (2016). Sustainability management with the Sustainability Balanced Scorecard in SMEs: Findings from an Austrian case study. Sustainability, 8, 545, 1-17. https://doi.org/10.3390/su8060545

Figge, F., Hahn, T., Schaltegger, S., \& Wagner, M. (2002). The sustainability balanced scorecardLinkingsustainability management to business strategy. Business Strategy and the Environment, 11(5), 269284.

\section{https://doi.org/10.1002/bse.339}

Gekonge, C. O. (2005). What a System!. The Professional Journal of KASNEB, 4.

Gminder, C. U., \& Bieker, T. (2002). Managing corporate social responsibility by using the "sustainabilitybalanced scorecard". In Hansen, E.G., \& Schaltegger, S. (2016). The Sustainability Balanced Scorecard: A Systematic Review of Architectures. Journal of Business Ethics, 133, 193-221. https://doi.org/10.1007/s10551-014-2340-3

Gulin, D., Janković, S., Dražić Lutilsky, I., Perčević, H.,Perišić, \& M. Vašiček, V. (2011). Upravljačko računovodstvo. Hrvatska zajednica računovođa i financijskih djelatnika: Zagreb. Retrieved 20 September 2020, from https://www.bib.irb.hr/507394

Hansen, E.G., \& Schaltegger, S. (2016). The Sustainability Balanced Scorecard: A systematic review of architectures. Journal of Business Ethics, 133, 193-221. https://doi.org/10.1007/s10551-014-2340-3
Hansen, E.G., \& Schaltegger, S. (2018). Sustainability Balanced Scorecards and their architectures: Irrelevant or misunderstood?. Journal of Business Ethics, 15, 937-952. https://doi.org/10.1007/s10551-017-3531-5

Hočevar, M. (2007). Prednosti i slabosti uravnoteženih pokazatelja (balanced scorecard). RRiF, 17(11) 56-60.

Hockerts, K., \& Wüstenhagen, R. (2010). Greening Goliaths versus emerging Davids: Theorizing about the role of incumbents and new entrants in sustainable entrepreneurship. Journal of Business Venturing, 25, 481-492. https://doi.org/10.1016/j.jbusvent.2009.07.005

Hristov, I., Chirico, A., Appolini, A. (2019). Sustainability value creation, survival, and growth of the company: A Critical Perspective in the Sustainability Balanced Scorecard (SBSC). Sustainability, 11(7), 1-19. https://doi.org/10.3390/su11072119

Hsu, C.-W., Hu, A. H., Chiou, C.-Y., \& Chen, T.-C. (2011).Using the FDM and ANP to construct a sustainability balanced scorecard for the semiconductor industry. Expert Systems with Applications, 38(10), 12891-12899. https://doi.org/10.1016/j.eswa.2011.04.082

Huang, T., Pepper, M., \& Bowrey, G. (2014). Implementinga Sustainability Balanced Scorecard to contribute to the process of organizational legitimacy assessment. Australian Accounting Business and Finance Journal, 8,15-34. https://doi.org/10.14453/aabfj.v8i2.3

Hubbard, G. (2009). Measuring organizational performance: Beyond the triple bottom line. Business Strategy and the Environment, 18, 177-191. https://doi.org/10.1002/bse.56

Jassem, S., Che Azmi, A. \& Zakaria, Z. (2018). Impact of Sustainability Balanced Scorecard types on environmental investment decisionmaking. Sustainability, 10(2), pp.1-18. https://doi.org/10.3390/su10020541

Jassem, S., Zakaria, Z., \& Che Azmi, A. (2020). Sustainability balanced scorecard architecture andenvironmental investment decision-making. Foundations of Management, 12, 193-210. https://doi.org/10.2478/fman-2020-0015

Jensen, M. C. (2001). Value maximization, stakeholder theory, and the corporate objective function. European Financial Management, 7(3), 297-317. https://doi.org/10.1111/1468-036X.00158

Jiangtao, L. \& Pin, Z. (2010). Analysis of Sustainability Balanced Scorecard influences ondecision processes and investment decisions. In Jassem, S., Zakaria, Z., \& Che Azmi, A. (2020). Sustainability balanced scorecard architecture andenvironmental investment decisionmaking. Foundations of Management, 12, 193-210. https://doi.org/10.2478/fman-2020-0015

Journeault, M. (2016). The integrated scorecard in support of corporate sustainability strategies. Journal of Environmental Management, 182, 214-229. https://doi.org/10.1016/j.jenvman.2016.07.074 
Kaplan, R. S., \& Norton, D. P. (1992). The balanced scorecard-Measures that drive performance. HarvardBusiness Review, 70, 71-79.

Kaplan, R. S., \& Norton, D. P. (1996). The balanced scorecard: Translating strategy into action. Boston, MA: Harvard Business School Press.

Kaplan, R. S., \& Norton, D. P. (2001). The strategy-focused organization: How balanced scorecard companies thrive in the new business environment. Boston, MA: Harvard Business School Press.

Kaplan, R. S., \& Norton, D. P. (2004). Strategy maps: Converting intangible assets into tangible outcomes. Boston, MA: Harvard Business School Press.

Kaplan, S.E. \& Wisner, P.S. (2009). The Judgmental Effects of Management Communications and a Fifth Balanced Scorecard Category on Performance Evaluation. In Jassem, S., Zakaria, Z., \& Che Azmi, A. (2020). Sustainability balanced scorecard architecture andEnvironmental investment decisionmaking.Foundations of Management, 12, 193-210. https://doi.org/10.2478/fman-2020-0015

Kellen, V. \& Wolf, B. (2003). Business performance measurement. Information Visualization, 1(312), 1-36. Retrieved 5 September, 2020, from http://www.redalyc.org/articulo.oa?id=499151079006.

Lončarević, M. (2006). Sustav uravnoteženih ciljeva u funkciji uspješnosti poslovanja, Ekonomski Pregled, 57 (1-2), 97-129. Retrieved 20 September, 2020, from https://hrcak.srce.hr/8041.

Medakovic, Dj. (2010). The importance of Balanced Scorecard model for monitoring the success of the small and medium enterprises. In Jelenić, D. (2011). The importance of knowledge management in organizations - with emphasis on the balanced scorecard learning and growth perspective.

Management, Knowledge and Learning International Conference, 1-11. Retrieved 20 September, 2020 from http://issbs.si/press/ISBN/978-961-92486-38/papers/ML11-1.pdf.

Mitton, T. (2002). A cross-firm analysis of the impact of corporate governance on the East Asian financial crisis. Journal of financial economics, 64(2), 215-241. https://doi.org/10.1016/S0304-405X(02)00076-4

Montemari, M., Chiucchi, M. S., \& Nielsen, C. (2019). Designing performance measurement systems usingbusiness models. Journal of Business Models, 7(5), 48-69. Retrieved 20 September 2020, from https://journals.aau.dk/index.php/JOBM/article/view/190 5/3199.

Nikolaou, I. E., \& Tsalis, T. A. (2013). Development of a sustainable balanced scorecard framework. Ecological Indicators, 34, 76-86. https://doi.org/10.1016/j.ecolind.2013.04.005

Osagie, E.R., Vesselink, R., Blok, V., Lans, T., \& Mulder, N. (2014). Individual competencies for corporate social responsibility: A literature and practice perspective. Journal of Business Ethics, 135(2), 233-252. https://doi.org/10.1007/s10551-014-2469-0

Schaltegger, S., \& Wagner, M. (2006). Integrative management of sustainability performance, measurement and reporting. International Journal of Accounting, Auditing and Performance Evaluation, 3(3), $1-19$. https://doi.org/10.1504/IJAAPE.2006.010098
Schaltegger, S., \& Wagner, M. (2011). Sustainable entrepreneurship and sustainability innovation: Categories and interactions. Business Strategy and the Environment, 20(4), 222-237. https://doi.org/10.1002/bse.682

Searcy, C. (2012). Corporate sustainability performance measurement systems: A review and research agenda. Journal of Business Ethics, 107(3), 239-253. https://doi.org/10.1007/s10551-011-1038-z

Sehic, S., \& Dizdarevic, M. (2011). Primjena "Balanced Scorecard" modela u mjerenju performansi malih i srednjih poduzeća u Bosni i Hercegovini. Zbornik Ekonomskog Fakulteta u Zagrebu, 9(1), 215-224.

Sidiropoulos, M., Mouzakitis, Y., Adamides, E. \& Goutsos, S. (2004). Applying sustainable indicators to corporatestrategy: The eco-balanced scorecard. Environmental Research, Engineering and Management, 1 (27): 28-33. Retrieved 20 September 2020, from https://www.researchgate.net/publication/228426761_A pplying_sustainable_indicators_to_corporate_strategy_ The_eco-balanced_scorecard.

Simmons, R. (2000). Performance Measurement and Control Systems for Implementing Strategy. New Jersey: Prentice Hall.

Sofiyabadi, J., \& Nasab, S. (2012). A dynamic balanced scorecard for identification internal process factor. Management Science Letters, 2(5), 1721-1730. https://doi.org/10.5267/j.msl.2012.04.015

Sorooshian, S., Aziz, N. F., Ahmad, A., Jubidin, S. N. \& Mustapha, N. M. (2016). Review on performancemeasurement systems. Mediterranean Journal of Social Sciences. 7(1), 123-132. Retrieved 1 August 2020, from https://www.mcser.org/journal/index.php/mjss/article/vie w/8652/8311.

Sundin, H., Granlund, M., \& Brown, D. A. (2010). Balancing multiple competing objectives with a balanced scorecard. European Accounting Review, 19(2), 203246. https://doi.org/10.1080/09638180903118736

Van Marrewijk, M. (2004). A value based approach to organization types: Towards a coherent set of stakeholder-oriented management tools. Journal of Business Ethics, 55(2), 147-158. https://doi.org/10.1007/s10551-004-1898-6

Voelpel, S. C., Leibold, M., \& Eckhoff, R. A. (2006). Thetyranny of the Balanced Scorecard in the innovation economy. Journal of Intellectual Capital, 7(1), 43-60. https://doi.org/10.1108/14691930610639769

Vrdoljak Raguž, I. (2010). Specifičnosti metodoloških pristupa mjerenju uspješnosti poslovanja kvalitativnim pokazateljima. Poslovna izvrsnost, 4(2), 107-117. Retrieved 20 September 2020, from https://hrcak.srce.hr/60702

Wati, Y. \& Koo., C. (2011). An Introduction to the Green IT balanced scorecard as a strategic IT management system. System Sciences (HICSS), 2011, 44th Hawaii International Conference on. 2011. IEEE. https://doi.org/10.1109/HICSS.2011.59 
World Bank. In Kitzmuller, M. (2008). Economics and Corporate Social Responsibility (EUI working paper),European University Institut. Retrieved 12 September, 2018, from

http://195.130.87.21:8080/dspace/bitstream/123456789 /1172/1/Economics\%20and\%20corporate\%20social\%2 Oresponsibility.pdf

\section{$\bowtie$ Correspondence}

\section{Sanda Rašić Jelavić}

Faculty of Economics \& Business, University of Zagreb Organization and Management Department Kennedyev trg 6, 10000 Zagreb, Croatia

E-mail: srasic@efzg.hr
World Business Council for Sustainable Development (2005) Eco-efficiency. Learning module. Geneva: WBSCD. 